\title{
THE INFLUENCE OF POLYETHER SUBSTITUENTS ON BIOLOGICAL ACTIVITY OF CURCUMIN DERIVATIVES
}

\author{
TOMASZ DEPTUŁA ${ }^{1}$, ADAM KRÓWCZYŃSKI ${ }^{1}$, IRENA BUBKO² \\ and BEATA MARIA GRUBER-BZURA ${ }^{2 *}$
}

\author{
${ }^{1}$ Faculty of Chemistry, University of Warsaw, 1 Pasteura St., 02-093 Warsaw, Poland \\ ${ }^{2}$ Department of Biochemistry and Biopharmaceuticals, National Medicines Institute, \\ 30/34 Chełmska St., 00-725 Warsaw, Poland
}

\begin{abstract}
Curcumin is reported as an anti-proliferative and chemopreventive compound. However, it shows poor water solubility, low bioavailability, and rapid metabolism. To address these problems, curcumin derivatives substituted with polyether chain were synthesized to improve the hydrophilicity of curcumin and thus its bioavailability. The biological activity of modified curcumin molecules were studied with human normal Blymphocytes GM 14667 and human leukemia cells HL60 and covered: the denotation of $\mathrm{IC}_{50}$ values for each new compound with use of MTT test and the studies on apoptosis induction observed as morphological changes and the expression of apoptotic proteins, BAX, BCL-2 and survivin with use of Western Blot analysis. All effects were referenced to native curcumin. The derivatives with modified polyether chains number and the position of methoxy groups were selected for further studies. As was shown, the solubility of the compound does not directly correlate with its cytotoxicity. The maintenance of the methoxy group in the meta position, as well as the introduction of hydrophilic polyether chains but not the number of polyether chains, may affect the cytotoxic activity of curcumin derivatives against cancer cells. Modifications of the curcumin molecule structure can determine its impact on the profile of pro- or anti-apoptotic proteins.
\end{abstract}

Keywords: curcumin derivatives, chemical synthesis, cytotoxic activity, antitumor drugs

Curcumin is a yellow dye isolated from the root of turmeric (Curcuma longa) (1). Curcumin in the form of popular spice, the curry, is consumed by approximately one-fourth of the world's population (1). Chemically, it is a symmetric molecule also known as diferuloyl methane with chemical formula $\mathrm{C}_{21} \mathrm{H}_{20} \mathrm{O}_{6}$. It has three chemical entities in its structure: two aromatic ring systems containing omethoxy phenolic groups, connected by a seven carbon linker consisting of an $\alpha, \beta$-unsaturated $\beta$-diketone moiety. The diketo group exhibits keto-enol tautomerism, which can exist in different types of conformers depending on the environment (Scheme 1) (2). The first chemical synthesis of curcumin was accomplished by the Polish chemist Wiktor Lampe $(3,4)$. Numerous research has shown that curcumin can be used in both anticancer therapy and chemoprevention. It was found that curcumin may reduce cancer growth, e.g. by apoptosis induction in cancer cells or by metastasis inhibition. There have been reports in the literature showing that curcumin increases the sensitivity of cancer cells to chemo- or radiotherapy (5, 6-9).

Curcumin has many well-known properties which could be used not only in the anticancer therapy such as anti-inflammatory activity, antioxidant properties, immunosuppressive and neuroprotective activities, metal-binding ability or antiprotozoal activity (10). The crucial advantage of curcumin as a compound of potential medical use is that it has no significant toxic effects (11-14). Sensitivity of specific tumor cell lines to curcumin confirmed in the studies, creates hope for using this compound in the therapy of cancer, including leukemia, stomach cancer, urogenital cancers, lung cancer, ovarian cancer, head and neck cancer, liver cancer, melanoma, cancer of the nervous system and the muscles. It is, therefore, a rationale for further research in this area: both in vitro, in vivo, and clinical studies (3, 15-17). Like many other compounds classified as antioxidants, curcumin may have a pro-oxidant effect under certain conditions. This is one of the proposed

* Corresponding author: e-mail: b.gruber@nil.gov.pl 

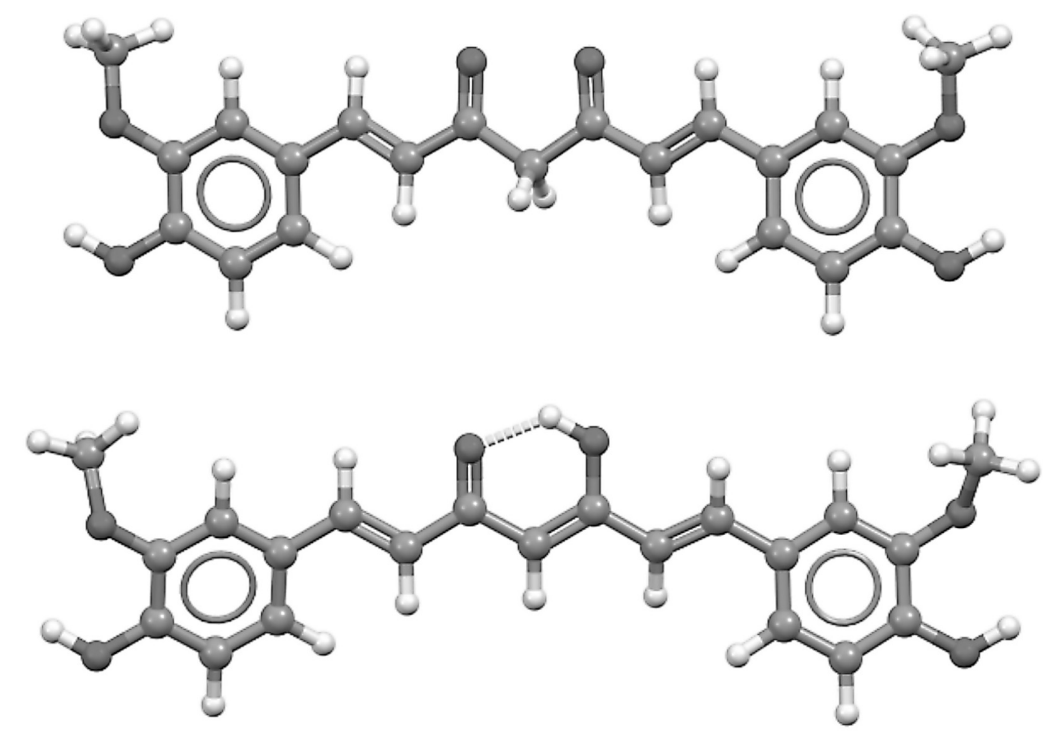

Scheme 1. The structure of curcumin in the keto-(upper structure) or enol- (lower structure) tautomer. Intramolecular hydrogen bonding stabilizes the enol form.

mechanisms in which curcumin induces apoptosis in cancer cells, besides the effect on mitochondrial release or expression of proapoptotic proteins $(18$, 19). The most important is that curcumin induces apoptosis in a cell-specific and selective way. Jiang et al. (20) found that curcumin can induce apoptosis in human lymphoblastoid $\mathrm{T}$ (Jurkat) cells but it has no effect on normal, non-immortalized mouse fibroblasts. Other possible mechanisms of proapoptotic activity of curcumin include its effect on transcription factors like NFkB or p53. Some authors showed the influence of curcumin on the expression of the proteins related to apoptosis induction, as BCL-2 (21).

The usefulness of curcumin may be limited by some properties determining its possible use as an active substance in medicinal products. In fact, curcumin is unstable in dissolved form, it is insoluble in water, and too rapidly metabolized in vivo (22).

The current progress in many areas of science allows modifying the pharmacokinetic properties of a given compound. One possibility is to design and synthesize derivatives characterized by improved bioavailability and slower metabolism compared to the parent molecule via, for example the introduction of substituents into the aromatic rings or formation of curcumin complexes. Another possibility is the use of adjuvants, nanoparticles, micelles, liposomes, cyclodextrins, and phospholipid complexes to improve bioavailability and attempts are made at using these solutions for curcumin (23-24). Relying on the reactivity of the phenol groups present in the curcumin molecule, it can be predicted that the structure of curcumin can be easily modified (25). In the naturally occurring curcumin, one phenol group at each of the rings forms an ether bond (the most stable modification of the phenol group) with a methyl substituent. It was shown that the resulting methoxy group determines the cytotoxic activity of curcumin, which has been demonstrated in studies involving the cancer cells $(10,26,27)$. As was also shown, the derivatives of this type have better stability $(8,27)$. So, the simplest of aromatic rings modification is the change the places of the phenol and methoxy groups. As was shown, the anti-proliferative effect of such derivative, called isocurcumin was comparable to that of curcumin; however, it had a weaker antioxidant activity (1). As demonstrated in vitro using human melanoma cells RPMI 7951 and human breast cancer cells MDA-MB-23, the best location for the phenol group in the curcumin molecule, in the absence of a methoxy group, in the context of cytotoxic activity, was the ortho position, while the meta and para positions have proved to be less active. It also appears that the oxygen linked to the aromatic ring is important for the anticancer activity of curcumin. Replacing it with a halogen or an alkyl chain results in a loss of anticancer activity (28). In turn, the derivatives containing polyethers act primarily by complexation and transporting metal ions through the cell membrane. This may potentially result in the induction of apoptosis, cell 
cycle arrest, the occurrence of oxidative stress and loss of mitochondrial potential (29).

On the basis of the above data concerning the relation between the structure of curcumin molecule and biological activity, the aim of the study was:

- to synthesize the curcumin derivatives having improved solubility in water via the following modifications of the curcumin molecule: the distribution and number of phenol groups in the aromatic rings and their blocking in the reactions to create an ester, ether or acetal with confirmation of the newly synthesized structure with NMR;

- to study how the obtained derivatives affect cytotoxic activity $\left(\mathrm{IC}_{50}\right)$ and apoptotic induction evaluated by cell morphology and anti- and proapoptotic proteins expression (survivin, BAX and BCL-2) in normal human B-lymphocyte GM14467 and human promyelocytic leukemia HL60 with use of colorimetric test and Westernblot method, respectively.

\section{MATERIALS AND METHODS}

\section{Synthesis of curcumin derivatives Synthesis of aldehyde derivatives}

Polyether benzaldehyde derivatives were obtained from the corresponding hydroxy derivatives of this aldehyde (Sigma-Aldrich) and 1-chloro3-oxa-butane or 1-chloro-3,6-dioxaheptane by Williamson's reaction.

\section{Synthesis of formyl crown ether derivative}

4'-formylbenzo-18-crown-6 was obtained from benzo-18-crown-6 (Sigma-Aldrich) by Vilsmeier-Haack reaction according to the procedure described by O.P. Kryatova in the paper which describes this compound (30). It was a substrate for the synthesis of compound 7.

Table 1. Efficiency of the synthesis of curcumin and compounds 1-7.

\begin{tabular}{|c|c|}
\hline Compound & Efficiency (\%) \\
\hline Curcumin & 86 \\
\hline $\mathbf{1}$ & 77 \\
\hline $\mathbf{2}$ & 62 \\
\hline $\mathbf{3}$ & 60 \\
\hline $\mathbf{4}$ & 67 \\
\hline $\mathbf{5}$ & 67 \\
\hline $\mathbf{6}$ & 59 \\
\hline $\mathbf{7}$ & 52 \\
\hline
\end{tabular}

\section{Synthesis of curcumin derivatives}

The reactions were carried out by the method proposed by Pabon (31). Acetylacetone (4 g, $40 \mathrm{mmoL}$ (Reachim) was dissolved in $40 \mathrm{~mL}$ of ethyl acetate (Sigma-Aldrich) and $2 \mathrm{~g}(28 \mathrm{mmoL})$ of boron trioxide (POCh) was added. The solution was stirred using a magnetic stirrer for $30 \mathrm{~min}$ at $40^{\circ} \mathrm{C}$. Then, $90 \mathrm{mmoL}$ of the respective benzaldehyde derivative and $40 \mathrm{~mL}$ of tributyl borate (Sigma-Aldrich), $0.15 \mathrm{mmoL}$ were added, and the mixture was stirred for $30 \mathrm{~min}$. After this time $6 \mathrm{~mL}$ of butylamine (POCh), $60 \mathrm{mmoL}$, dissolved in $40 \mathrm{~mL}$ of ethyl acetate was added dropwise over $15 \mathrm{~min}$. Stirring was continued for $24 \mathrm{~h}$ at $40^{\circ} \mathrm{C}$. The resulting boron complex was hydrolyzed by adding 120 $\mathrm{mL}$ of $4 \mathrm{~N}$ hydrochloric acid (POCh), followed by heating for $30 \mathrm{~min}$ at $60^{\circ} \mathrm{C}$. The reaction was monitored by thin-layer chromatography (silica gel, $\mathrm{CH}_{2} \mathrm{Cl}_{2}$ /acetone). The reaction mixture was neutralized with sodium bicarbonate (POCh) and the product was extracted with ethyl acetate. The product was pre-purified by column chromatography using methylene chloride (POCh): acetone (POCh), 20:1 as the eluent. The pure product was obtained by preparative TLC using methylene chloride: acetone 9:1.

\section{NMR spectroscopy}

NMR spectra were recorded on a $500 \mathrm{MHz}$ spectrometer; the compounds were dissolved in chloroform-d3.

\section{Cell cultures}

In this study, the following cell lines were used: human B-lymphocyte GM14467 (Coriell Institute); human promyelocytic leukemia HL60 (American Type Culture Collection). Both cell lines were cultured in Minimum Essential Medium with $10 \%$ of fetal bovine serum (Lonza) and $1 \%$ of Antibiotics, Antimycotic (Penicillin, Streptomycin) (Lonza) at $37^{\circ} \mathrm{C}$ and $5 \% \mathrm{CO}_{2}$.

Cell cultures used in the study were routinely checked for mycoplasma with the use of RT-PCR technique.

\section{Studies on cell viability}

Cell viability was tested by the ready-to-use EZ4U test (Biomedica). The cells were seeded in 96 -well plates $\left(3 \times 10^{3} /\right.$ well $)$ and were resuspended in a growth medium containing the tested compounds at the following concentrations: $10,15,20$, $25,30,40,50 \mu \mathrm{M}$. The control cultures were the intact cells resuspended in the fresh medium. After $24 \mathrm{~h}$ of incubation at $37^{\circ} \mathrm{C}, 20 \mu \mathrm{L}$ of the EZ4U 
reagent was added to the wells and the plate was incubated for the next $4 \mathrm{~h}$. After that time, absorption of the colored solutions was measured by microplate reader IEMS Reader MF, at wavelengths of $492 \mathrm{~nm}$ and $620 \mathrm{~nm}$.

\section{Evaluation of cell morphology}

Cell morphology was observed with the use of fluorescence microscope Nikon Eclipse TS100-F. $0.1 \mathrm{~mL}$ of the cell suspension with a density of approx. $10^{6} / \mathrm{mL}$, previously exposed for $24 \mathrm{~h}$ to the

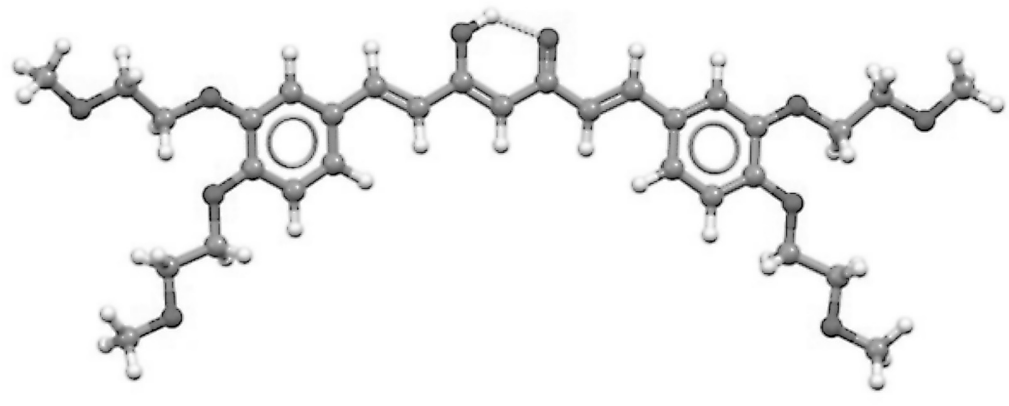

Scheme 2. Compound $\mathbf{1}\left(\mathrm{C}_{31} \mathrm{H}_{40} \mathrm{O}_{10}, 572 \mathrm{~g} / \mathrm{mole}\right)$.

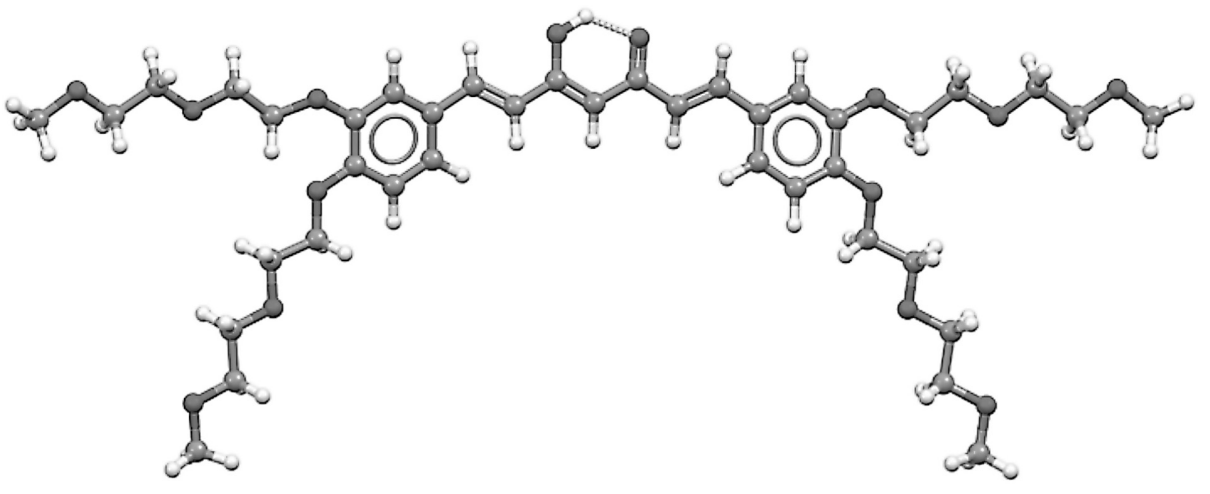

Scheme 3. Compound $2\left(\mathrm{C}_{39} \mathrm{H}_{56} \mathrm{O}_{14}, 748 \mathrm{~g} / \mathrm{mole}\right)$.

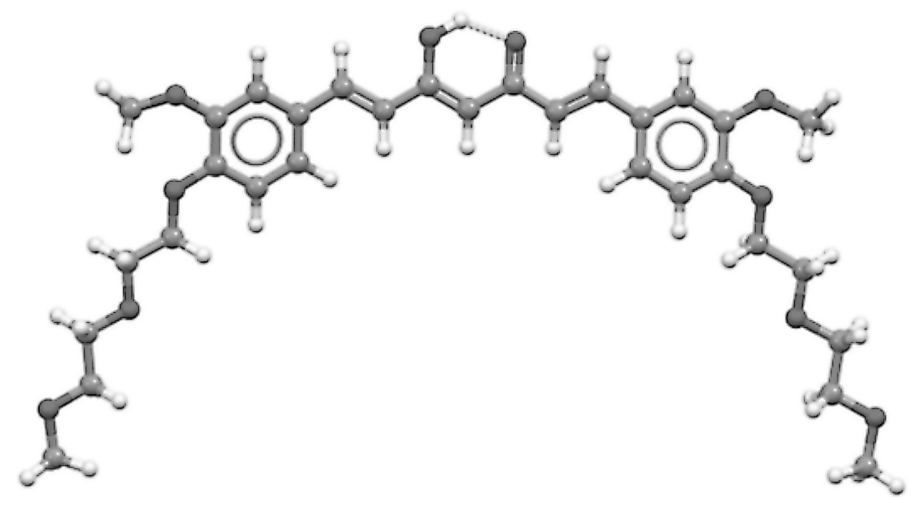

Scheme 4. Compound $3\left(\mathrm{C}_{31} \mathrm{H}_{40} \mathrm{O}_{10}, 572 \mathrm{~g} / \mathrm{mole}\right)$. 


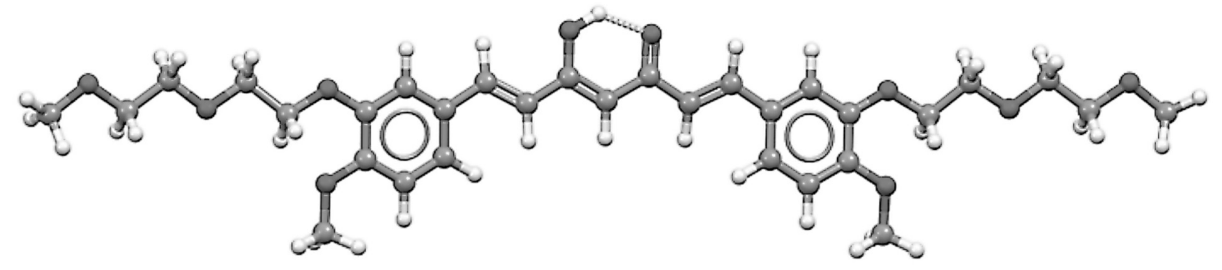

Scheme 5. Compound $4\left(\mathrm{C}_{31} \mathrm{H}_{40} \mathrm{O}_{10}, 572 \mathrm{~g} / \mathrm{mole}\right)$.

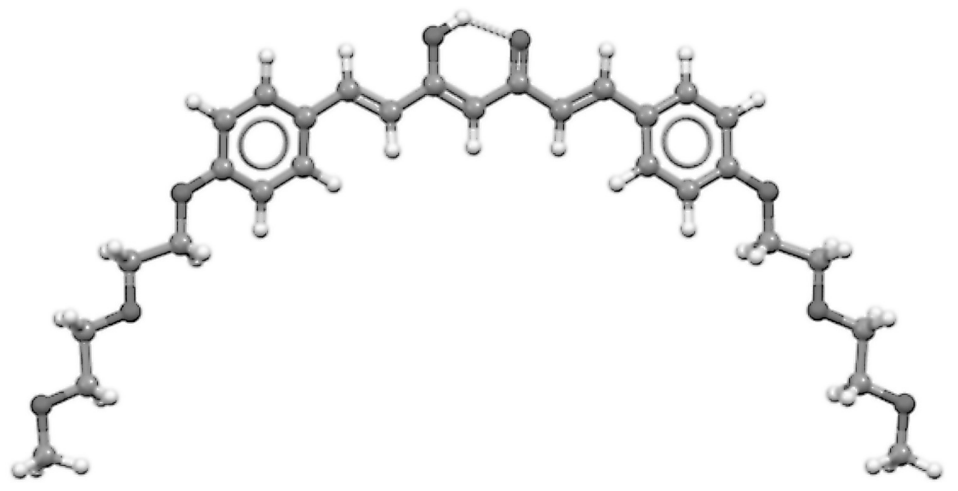

Scheme 6. Compound $5\left(\mathrm{C}_{29} \mathrm{H}_{36} \mathrm{O}_{8}, 512 \mathrm{~g} / \mathrm{mole}\right)$.
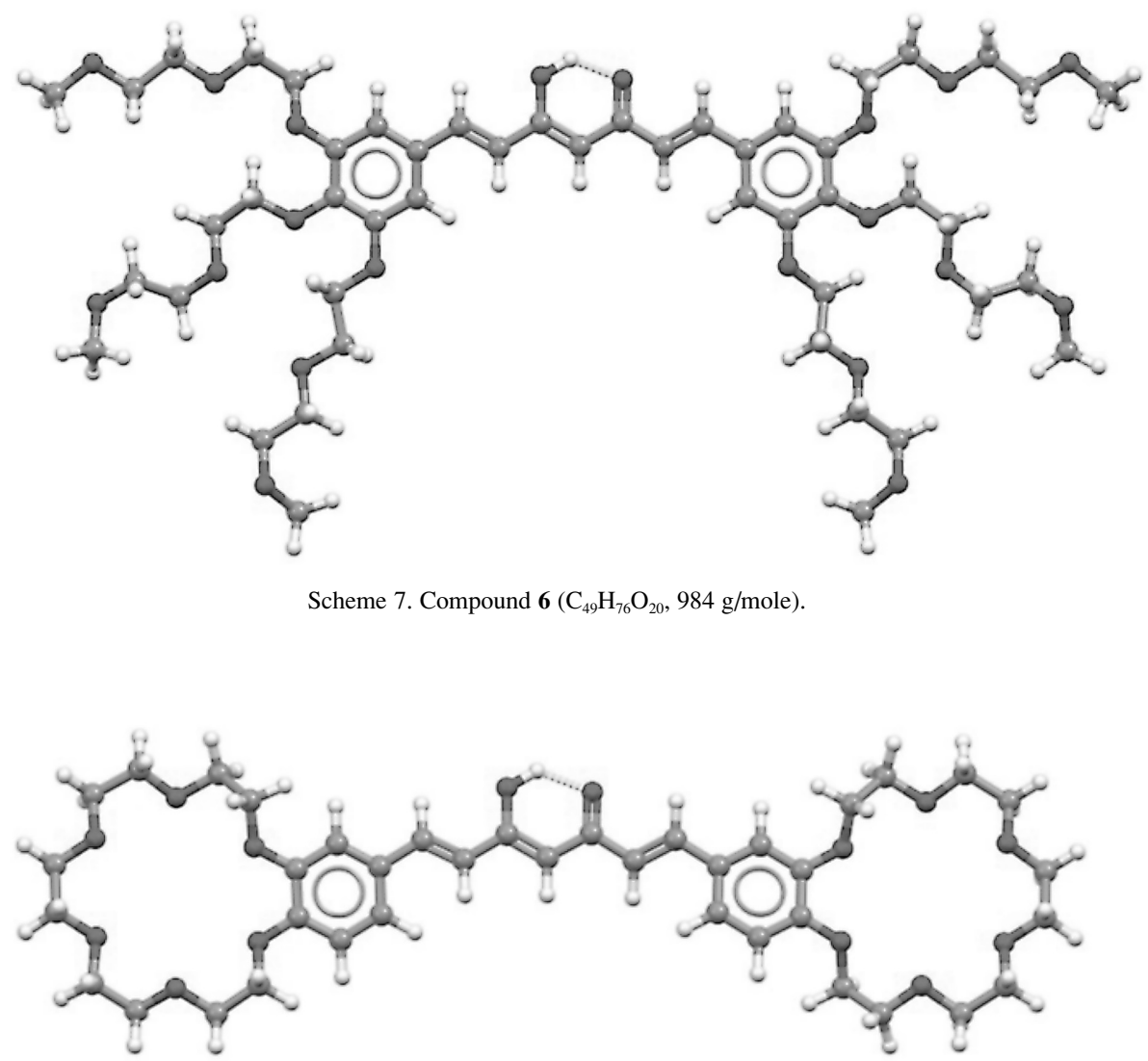

Scheme 8. Compound $7\left(\mathrm{C}_{39} \mathrm{H}_{52} \mathrm{O}_{14}, 744 \mathrm{~g} / \mathrm{mole}\right)$ 
compounds, was mixed with $0.1 \mathrm{~mL}$ of DAPI (Molecular Probes) solution $(1.0 \mu \mathrm{g} / \mathrm{mL})$ in phosphatebuffered saline (PBS) (IITD, Wroclaw, Poland) and then, placed on the slide and analyzed under the microscope.

GM14467 cells were exposed for $24 \mathrm{~h}$ to curcumin at concentrations of $14 \mu \mathrm{m}$ and $28 \mu \mathrm{m}$ or to compound 3 at concentrations of $5 \mu \mathrm{M}$ and $9 \mu \mathrm{M}$. HL60 cells were exposed for $24 \mathrm{~h}$ to curcumin at concentrations of $12 \mu \mathrm{M}$ and $24 \mu \mathrm{M}$, or to compound 3 at concentrations of $8 \mu \mathrm{M}$ and $15 \mu \mathrm{M}$.

\section{The study of protein expression Preparation of cell lysates}

$48 \mathrm{~h}$ cell cultures with a starting density of $3 \times 10^{5} / \mathrm{mL}$ were exposed for another $24 \mathrm{~h}$ to different concentrations of the tested compounds, equal to the appropriate half of $\mathrm{IC}_{50}$ or $\mathrm{IC}_{50}$ values defined for each of the cell lines. After that time, the cells were centrifuged at $2000 \mathrm{rpm}$ for $10 \mathrm{~min}$ at $+4^{\circ} \mathrm{C}$. The pellet was resuspended in $1.5 \mathrm{~mL}$ of PBS and centrifuged at $12.000 \mathrm{rpm}$ for $3 \mathrm{~min}$ in Eppendorf tubes, also at $+4^{\circ} \mathrm{C}$. The pellet was lysed for $15 \mathrm{~min}$ at $+4^{\circ} \mathrm{C}$ in $100 \mu \mathrm{L}$ of $\mathrm{CBE}$ buffer (Tris- $\mathrm{HCl}$, SigmaAldrich, $10 \mathrm{mM}$, pH 7.9; KCl, Sigma-Aldrich, 1 mM; EDTA, Sigma-Aldrich, $1 \mathrm{mM}$; dithiothreitol, Sigma-Aldrich, 1 mM; Nonidet P-40 (Igepal), 0.4\%; and Leupeptin, ICN Biomedica, $1 \mu \mathrm{g} / \mathrm{mL}$ ); Pepstatin A (Sigma-Aldrich), $1 \mu \mathrm{g} / \mathrm{mL}$; Aprotinin (ICN Biomedica), $2 \mu \mathrm{g} / \mathrm{mL}$; benzamidine (Sigma-Aldrich), $0.5 \mu \mathrm{g} / \mathrm{mL}$; PMSF (Sigma-Aldrich), $0.5 \mathrm{mM}$. After $15 \mathrm{~min}$, the samples were centrifuged at $12.000 \mathrm{rpm}$ for $5 \mathrm{~min}$ at $+4^{\circ} \mathrm{C}$, and the supernatants were collected.

\section{Western blot}

$30 \mu \mathrm{L}$ of the lysate (corresponding to approx. $80 \mu \mathrm{g}$ of protein) were incubated with $10 \mu \mathrm{L}$ of Laemmli's buffer (MetLab) and $10 \mu \mathrm{L}$ of Tris-HCl, $100 \mathrm{mM}, \mathrm{pH} 7.0$, at $100^{\circ} \mathrm{C}$ for $5 \mathrm{~min}$. After that time, the proteins were separated on $12 \%$ polyacrylamide gels (CBS Scientifical Company), $30 \mu \mathrm{L} /$ well. SDSPAGE electrophoresis was performed on polyacrylamide gel, $12 \%, 1.5 \mathrm{~h}, 10 \mathrm{~V}$, at $+4^{\circ} \mathrm{C}$, in buffer containing Tris $0.05 \mathrm{M}$, glycine $0.05 \mathrm{M}$ (Biochimica) and SDS (Sigma-Aldrich), 0.4 M.

Transfer of gel separated proteins onto a nitrocellulose membrane (Whatman; $0.45 \mathrm{~mm}$ ) was carried out for $2 \mathrm{~h}$ at $90 \mathrm{~V},+4^{\circ} \mathrm{C}$, in buffer containing: Tris, $27 \mathrm{mM}$; glycine, $27 \mathrm{mM}$; methanol (SigmaAldrich), $0.19 \mathrm{M}$ (final methanol concentration $20 \%$ ). Protein transfer efficiency was checked by Ponceau S stain (Sigma-Aldrich), which was then washed out three times with water at room tempera- ture. Protein blocking on the membrane was performed at room temperature, for $2 \mathrm{~h}$, in a solution of $5 \%$ skim milk powder, on a laboratory cradle. The hybridization was done by adding primary monoclonal antibodies: rabbit anti-BCL-2 (Eppendorf), $1: 250$, rabbit anti-Bax (Eppendorf), $1: 125$, rabbit anti-survivin (Eppendorf), $1: 67$, at $+4^{\circ} \mathrm{C}$, overnight, on a shaker. $\beta$-actin detection was carried out using an anti- $\beta$-actin mouse antibody (Therms Scientica), $1: 17,000$, for $1 \mathrm{~h}$, at $+4^{\circ} \mathrm{C}$.

Then, after 3-fold washing out of the unbound primary antibodies with skimmed milk solution in PBS-T (PBS $+0.1 \%$ of Tween-20), the proteins on the membrane were labeled by secondary anti-rabbit antibodies for $2 \mathrm{~h}$ (Sigma), 1:500 or anti-mouse antibodies (Sigma), 1:500, at room temperature. After washing out of the secondary antibodies, the bands corresponding to the tested proteins were detected using the HRP Colour Development Reagent kit (Bio-Rad) according to the manufacturer's instructions. The reagents were prepared ex tempore. The identity of the bands was confirmed $v s$. the target molecular weights $(10,17,26,34,43,55,72,95$, 130, $170 \mathrm{kDa}$ ) (Fermentas). The results were archived using Gel Doc 2000 (Bio-Rad).

\section{Protein assay by Bradford method}

The measurements were performed against demineralized water, in samples containing $2 \mu \mathrm{L}$ of cell lysate and $18 \mu \mathrm{L}$ of demineralized water. $1 \mathrm{~mL}$ of an aqueous solution of Bradford reagent (SigmaAldrich), $1: 4$ was added to each sample. The samples with the reagent were incubated for $10 \mathrm{~min}$ at room temperature. The measurement was performed on a biophotometer (Eppendorf) at a wavelength of $595 \mathrm{~nm}$. Protein content (in $\mu \mathrm{g} / \mathrm{mL}$ ) in each sample was calculated based on a calibration curve prepared by using serial dilutions of albumin solution with a known concentration.

\section{RESULTS}

\section{Synthesis of curcumin derivatives}

The aldehyde, which was the substrate for the synthesis of compound 4, was prepared from isovanillin and 1-chloro-3,6-dioxaheptane by Williamson reaction, with a reaction yield of $91 \%$. The other aldehyde substrates for the synthesis of compound 1-6, were synthesized with yields exceeded $90 \%$, except for the synthesis of the aldehyde with a polyether substituent at positions $3,4,5$, the substrate for the synthesis of compound 7 where the yield was $74 \%$.

The synthesis of curcumin derivatives was carried out in accordance with the procedure described 
by Pabon (31). The resignation of washing the reaction mixture with water in order to separate the excess hydrochloric acid was the necessary modification of the procedure. Instead, the acid was neutralized by solid potassium bicarbonate and extracted with ethyl acetate. This modification has been introduced due to the significant water solubility of the obtained curcumin derivatives because extraction by water would result in losing a significant part of the product. The yields for curcumin derivatives synthesis are shown in Table 1. The formulas of the obtained derivatives are shown in Schemes 2-8.

As was shown in Table 1 the lowest yield, i.e. below $60 \%$ was obtained for the derivatives with the highest number of polyether chains, i.e. those showing the highest solubility in water. For compounds 6 and 7 , it was necessary to perform purification by thin-layer chromatography (cellulose, methylene chloride, $1: 4$ hexane).

The structures of all compounds obtained in this study were proved by NMR and elementary analysis as presented below:

Compound 1: ${ }^{1} \mathrm{H}$ NMR $\left(\mathrm{CDCl}_{3}\right): \delta=3.46(\mathrm{~s}, 6 \mathrm{H})$; 3.47 (s, 6H), 3.77-3.80 (m, 8H); 4.18-4.22 (m, 8H); $5.79(\mathrm{~s}, 1 \mathrm{H}) ; 6.48$ and $7.58(\mathrm{AB}, J=15.7 \mathrm{~Hz}, 4 \mathrm{H})$; $6.91(\mathrm{~d}, J=8.1 \mathrm{~Hz}, 2 \mathrm{H}) ; 7.12(\mathrm{~d}, J=1.9 \mathrm{~Hz}, 2 \mathrm{H})$; $7.14(\mathrm{dd}, J=8.1 \mathrm{~Hz}, 1.9 \mathrm{~Hz}, 2 \mathrm{H}) 15.96$ (s, 1H). Elementary analysis of $\mathrm{C}_{31} \mathrm{H}_{40} \mathrm{O}_{10}$ : theoretical: $\mathrm{C}$, $65.02 \%$; H, 7.04\%; found: C, $64.87 \%$; $\mathrm{H}, 6.97 \%$.

Compound 2: ${ }^{1} \mathrm{H}$ NMR $\left(\mathrm{CDCl}_{3}\right): \delta=3.38(\mathrm{~s}, 6 \mathrm{H})$; 3.39 (s, 6H), 3.69-3.92 (m, 24H); 4.08-4.25 (m, 8H); $5.81(\mathrm{~s}, 1 \mathrm{H}) ; 6.49$ and $7.58(\mathrm{AB}, J=15.6 \mathrm{~Hz}, 4 \mathrm{H})$; $6.97(\mathrm{~d}, J=8.1 \mathrm{~Hz}, 2 \mathrm{H}) ; 7.16(\mathrm{~d}, J=1.8 \mathrm{~Hz}, 2 \mathrm{H})$; 7.17 (dd, $J=8.1 \mathrm{~Hz}, 1.8 \mathrm{~Hz}, 2 \mathrm{H}) ; 16.02$ (s, 1H). Elementary analysis of $\mathrm{C}_{39} \mathrm{H}_{56} \mathrm{O}_{14}$ : theoretical: $\mathrm{C}$, $62.55 \%$; H, 7.54\%; found: C, $62.43 \%$; $\mathrm{H}, 7.67 \%$.
Compound 3: ${ }^{1} \mathrm{H}$ NMR $\left(\mathrm{CDCl}_{3}\right): \delta=3.46(\mathrm{~s}, 6 \mathrm{H})$; 3.55-3.93 (m, 18H); $4.19(\mathrm{t}, J=4.9 \mathrm{~Hz}, 4 \mathrm{H}) ; 5.82(\mathrm{~s}$, $1 \mathrm{H}) ; 6.50$ and $7.60(\mathrm{AB}, J=15.6 \mathrm{~Hz}, 4 \mathrm{H}) ; 6.92(\mathrm{~d}$, $J=8.2,2 \mathrm{H}) ; 7.08($ broad s, 2H); $7.12(\mathrm{~d}, J=8.2 \mathrm{~Hz}$, $2 \mathrm{H}), 16.03(\mathrm{~s}, 1 \mathrm{H})$. Elementary analysis of $\mathrm{C}_{31} \mathrm{H}_{40} \mathrm{O}_{10}$ : theoretical: $\mathrm{C}, 65.02 \%$; $\mathrm{H}, 7.04 \%$; found: C, $65.18 \%$; H $6.93 \%$.

Compound 4: ${ }^{1} \mathrm{H}$ NMR $\left(\mathrm{CDCl}_{3}\right): \delta=3.40(\mathrm{~s}, 6 \mathrm{H})$; 3.56-3.92 (m, 18H); $4.24(\mathrm{t}, J=5.1 \mathrm{~Hz}, 4 \mathrm{H}) ; 5.89(\mathrm{~s}$, $1 \mathrm{H}) ; 6.50$ and $7.62(\mathrm{AB}, J=15.9 \mathrm{~Hz}, 4 \mathrm{H}) ; 6.87(\mathrm{~d}$, $J=8.5 \mathrm{~Hz}, 2 \mathrm{H}) ; 7.04(\mathrm{~d}, J=2.0 \mathrm{~Hz}, 2 \mathrm{H}) ; 7.15(\mathrm{dd}$, $J=8.5,2.0 \mathrm{~Hz}, 2 \mathrm{H}) ; 15.98(\mathrm{~s}, 1 \mathrm{H})$. Elementary analysis of $\mathrm{C}_{31} \mathrm{H}_{40} \mathrm{O}_{10}$ : theoretical: $\mathrm{C}, 65.02 \%$; $\mathrm{H}$, 7.04\%; found: C, $64.88 \%$; H, 6.99\%.

Compound 5: ${ }^{1} \mathrm{H}$ NMR $\left(\mathrm{CDCl}_{3}\right): \delta=3.43(\mathrm{~s}, 6 \mathrm{H})$; 3.57-3.85 (m, 12H); $4.20(\mathrm{t}, J=4.8 \mathrm{~Hz}) ; 5.81(\mathrm{~s}$, $1 \mathrm{H}) ; 6.35$ and $7.38(\mathrm{AB}, J=15.9 \mathrm{~Hz}, 4 \mathrm{H}) ; 6.91$ and 7.51 (AA'BB', $J=8.7 \mathrm{~Hz}, 8 \mathrm{H}$ ); 16.02 (s, 1H). Elementary analysis of $\mathrm{C}_{29} \mathrm{H}_{36} \mathrm{O}_{8}$ : theoretical: $\mathrm{C}$, $67.95 \%$; H, 7.08\%; found: C, 68.02\%; H, 7.23\%.

Compound 6: ${ }^{1} \mathrm{H}$ NMR $\left(\mathrm{CDCl}_{3}\right): \delta=3.45(\mathrm{~s}, 12 \mathrm{H})$; $3.48(\mathrm{~s}, 6 \mathrm{H}) ; 3.58-3.94(\mathrm{~m}, 36 \mathrm{H}) ; 4.09-4.28(\mathrm{~m}$, $12 \mathrm{H}) ; 5.82(\mathrm{~s}, 1 \mathrm{H}) ; 6.49(\mathrm{~s}, 4 \mathrm{H}) ; 6.52$ and $7.53(\mathrm{AB}$, $J=15.6 \mathrm{~Hz}, 4 \mathrm{H}) ; 16.05$ (s, 1H). Elementary analysis of $\mathrm{C}_{49} \mathrm{H}_{76} \mathrm{O}_{20}$ : theoretical: C, $59.74 \% ; \mathrm{H}, 7.78 \%$; found: C, $59.84 \%$; $\mathrm{H}, 7.74 \%$.

Compound 7: ${ }^{1} \mathrm{H}$ NMR $\left(\mathrm{CDCl}_{3}\right): \delta=3.44-3.82(\mathrm{~m}$, $32 \mathrm{H})$; 4.17-4.22 (m, 8H); $5.81(\mathrm{~s}, 1 \mathrm{H}) ; 6.50$ and 7.76 $(\mathrm{AB}, J=15.6 \mathrm{~Hz}, 4 \mathrm{H}) ; 6.95(\mathrm{~d}, J=8.3 \mathrm{~Hz}, 2 \mathrm{H}) ; 7.16$ (d, $J=1.8 \mathrm{~Hz}, 2 \mathrm{H}) ; 7.18 \mathrm{dd}, J=8.3,1.8 \mathrm{~Hz}, 2 \mathrm{H})$; 15.99 (s, $1 \mathrm{H})$. Elementary analysis of $\mathrm{C}_{39} \mathrm{H}_{52} \mathrm{O}_{14}$ : theoretical: C, $62.89 \%$; H, $7.04 \%$; found: C, $62.88 \%$; $\mathrm{H}, 7.00 \%$.

Table 2. $\mathrm{IC}_{50}$ values $( \pm \mathrm{SD})$ for curcumin and compounds 1 - 7 defined with EZ4U test for GM 14667 and HL60 cells.

\begin{tabular}{|c|c|c|}
\hline Compounds & GM 14667 & HL60 \\
& $\mathrm{IC}_{50} \pm \mathrm{SD}(\mu \mathrm{M})$ & IC $_{50} \pm \mathrm{SD}(\mu \mathrm{M})$ \\
\hline Curcumin & $28 \pm 4$ & $24 \pm 1$ \\
\hline 1 & $32 \pm 9$ & $>50$ \\
\hline 2 & $12 \pm 1$ & $>50$ \\
\hline 3 & $9 \pm 1$ & $26 \pm 2$ \\
\hline 4 & $29 \pm 8$ & $>50$ \\
\hline 5 & $>50$ & $28 \pm 0$ \\
\hline 6 & $>50$ & $>50$ \\
\hline 7 & $40 \pm 1$ & 28 \\
\hline
\end{tabular}




\section{Studies on cell viability}

The EZ4U test allows the detection of live cells by their ability of enzymatic reduction of the tetrazolium salt with a yellow color to an intensely purple-colored formazan derivative $\left(\lambda_{\max }=492 \mathrm{~nm}\right)$. The increase in absorption at $\lambda_{\max }=492 \mathrm{~nm}$ is in a linear relationship to the number of living cells in the test culture.

The cytotoxic activity of the tested compounds were determined by the percentage of viable cells in the culture referenced to the unexposed culture (i.e. $100 \%$ live cells) and based on the concentration of the tested compound by determining the $\mathrm{IC}_{50}$ value, i.e. the concentration causing a $50 \%$ inhibition in culture growth, for each compound. The reference compound in the evaluation of the cytotoxic activity of the newly synthesized analogs was curcumin. The selection criteria for the compounds were $\mathrm{IC}_{50}$ values lower than for curcumin and selectivity towards antineoplastic cells expected as $\mathrm{IC}_{50}$ for $\mathrm{GM} 14467$ higher than $\mathrm{IC}_{50}$ for HL60. All results were compared with those obtained for curcumin.

The $\mathrm{IC}_{50}$ values defined for curcumin and newly synthesized derivatives are presented in Table 2.

As shown in Table 2 the $\mathrm{IC}_{50}$ values determined for curcumin in relation to GM14467 and HL60 cells were comparable and were $28 \mu \mathrm{M}$ and $24 \mu \mathrm{M}$, respectively. The cytotoxicity of new-synthesized compounds 4, 5 and 7 towards both cell lines was comparable with curcumin (compound 4) or significantly weaker than the reference compound (compound $\mathbf{5}$ and 7). Compounds $\mathbf{1}$ and $\mathbf{2}$ occurred as much weaker than curcumin only towards cancer cells HL60 ( $\left.\mathrm{IC}_{50}>50 \mu \mathrm{M}\right)$. Compound 2 exhibited stronger activity than curcumin but against normal lymphocytes GM $12667\left(\mathrm{IC}_{50}=12\right.$ $\mu \mathrm{M})$. While the expected selectivity was observed in the case of compound 6, i.e. $\mathrm{IC}_{50}$ value for HL60 cells occurred two-fold lower than for GM 14667 cells but it's cytotoxic activity towards cancer cells was similar to curcumin. Therefore, for studies on the mechanism of cytotoxicity the curcumin derivatives synthesized in this work, only compound $\mathbf{3}$ were selected as more cytotoxic for HL60 cells than curcumin although not selective as expected ( $\mathrm{IC}_{50}$ value for HL60 cells occurred only 1.5-fold lower than for GM 14667 cells).

\section{Studies on apoptosis induction \\ Evaluation of cell morphology}

Cell morphology of the cells was evaluated in the search for the specific features of apoptosis same as apoptotic bodies or chromatin condensation visible as a blue ring around the nucleus. It was performed by the microscopic method using a fluorescent dye DAPI, specific for DNA. Connection of DAPI with DNA results in blue fluorescence easily observable under the microscope.

GM14467 cells were exposed for 24 hours to curcumin at concentrations of $14 \mu \mathrm{m}$ and $28 \mu \mathrm{m}$ or to compound 3 at concentrations of $5 \mu \mathrm{M}$ and $9 \mu \mathrm{M}$. HL60 cells were exposed for $24 \mathrm{~h}$ to curcumin at con-

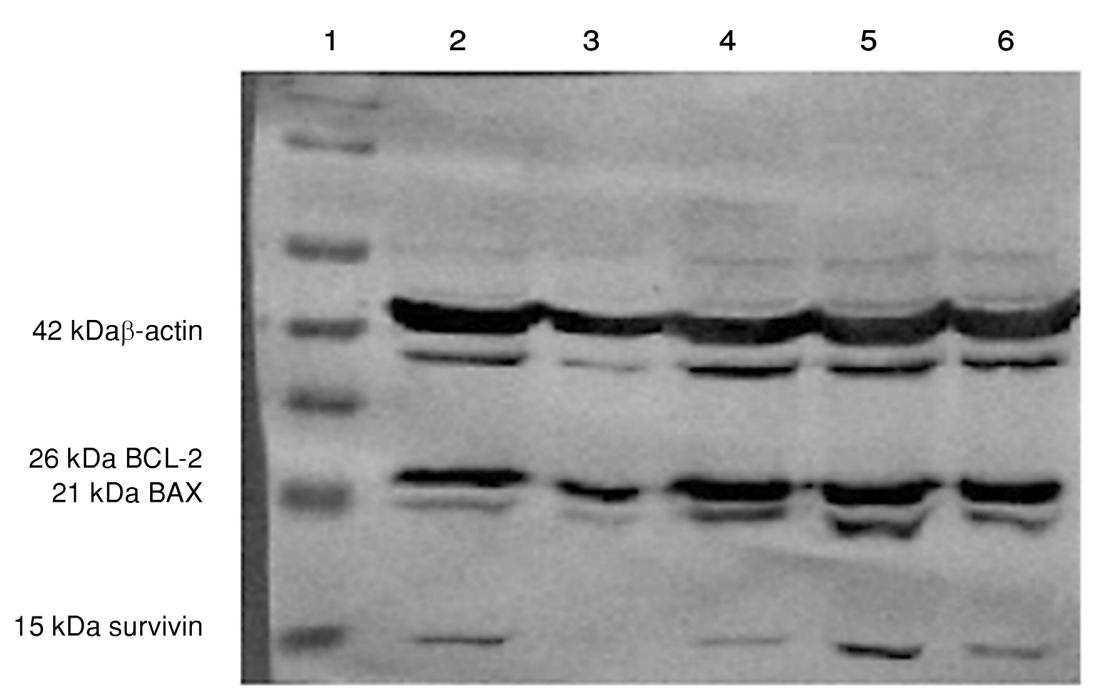

Figure 1. Whole cell extracts from GM 14667 cells corresponding to $80 \mu \mathrm{g}$ of protein were loaded onto gel and after electrophoresis transferred onto nitrocellulose membrane. Each protein was detected with respective primary and next secondary antibodies and visualized with HRP Colour Development Reagent as was described in Materials and methods. Lane 1. Protein mass standard. Lane 2. Control cells. Lane 3 and Lane 4. Cells treated with curcumin, $14 \mu \mathrm{M}$ and $28 \mu \mathrm{M}$, respectively for $24 \mathrm{~h}$. Lane 5 and Lane 6 . Cells treated with compound 3, 5 $\mu \mathrm{M}$ and $9 \mu \mathrm{M}$, respectively for $24 \mathrm{~h} .42 \mathrm{kDa}-\beta$-actin, $26 \mathrm{kDa}-\mathrm{BCL}-2,21 \mathrm{kDa}-\mathrm{BAX}, 16 \mathrm{kDa}$ - survivin. 


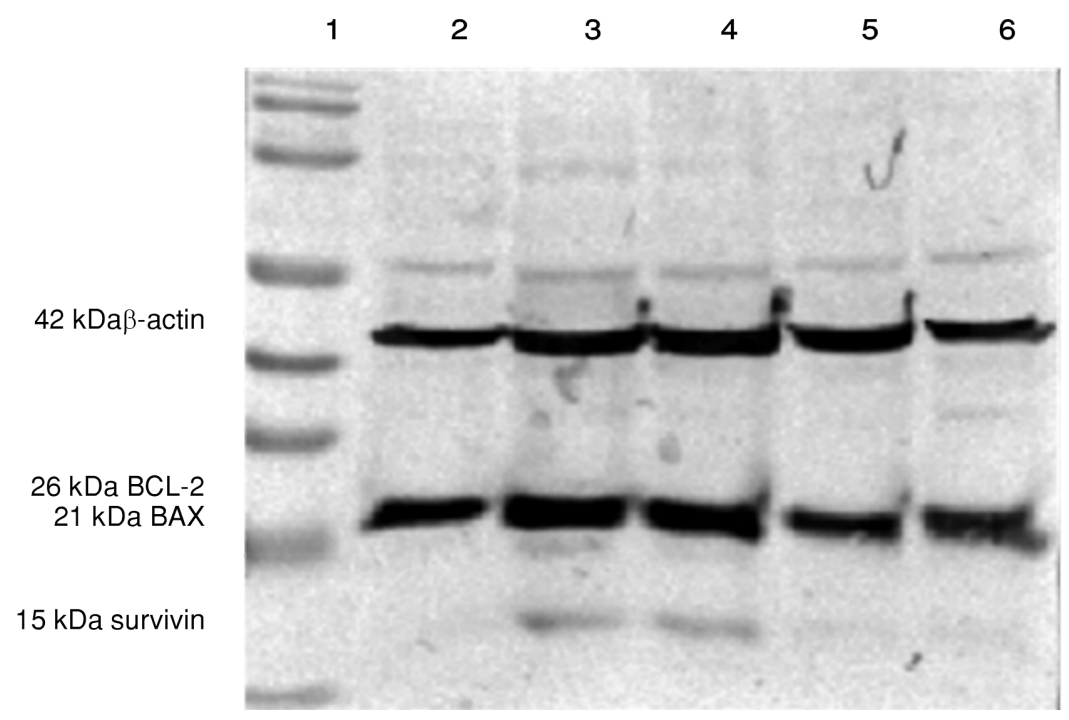

Figure 2. Whole cell extracts from HL60 cells corresponding to $80 \mu \mathrm{g}$ of protein were loaded onto gel and after electrophoresis transferred onto nitrocellulose membrane. Each protein was detected with respective primary and next secondary antibodies and visualized with HRP Colour Development Reagent as was described in Materials and methods. Lane 1. Protein mass standard. Lane 2. Control cells. Lane 3 and Lane 4. Cells treated with curcumin, $12 \mu \mathrm{M}$ and $24 \mu \mathrm{M}$, respectively for $24 \mathrm{~h}$. Lane 5 and Lane 6 . Cells treated with compound 3, $8 \mu \mathrm{M}$ and $15 \mu \mathrm{M}$, respectively for $24 \mathrm{~h} .42 \mathrm{kDa}$ - $\beta$-actin, $26 \mathrm{kDa}$ - BCL-2, $21 \mathrm{kDa}-\mathrm{BAX}, 16 \mathrm{kDa}$ - survivin.

centrations of $12 \mu \mathrm{M}$ and $24 \mu \mathrm{M}$, or to compound $\mathbf{3}$ at concentrations of $8 \mu \mathrm{M}$ and $15 \mu \mathrm{M}$, respectively. Based on microscopic observations, morphological features of apoptosis, mainly in the form of polar chromatin condensation, were seen only in GM14467 cells treated with curcumin or with compound $\mathbf{3}$ at concentrations equal to the appropriate $\mathrm{IC}_{50}$ values, i.e. 28 and $9 \mu \mathrm{M}$, respectively (data are not shown). Lower than $\mathrm{IC}_{50}$ concentrations of curcumin or compound 3, i.e. $14 \mu \mathrm{M}$ and $5 \mu \mathrm{M}$, respectively, did not induce visible signs of apoptotic changes in these cells (data not shown). HL60 cells did not exhibit apoptotic features at any of the concentrations of curcumin or compound $\mathbf{3}$ (data are not shown).

\section{Apoptotic proteins expression}

In this study, the expression of three apoptotic proteins, i.e. anti-apoptotic BCL-2, survivin, and pro-apoptotic BAX protein, was studied. The amount of protein applied to the gel was normalized relative to $\beta$-actin, one of the basic structural proteins in the cells.

As referenced to the protein profile detected in the intact cells (control cells), it can be said that the most effective inducer of all three proteins in GM 14667 cells was compound 3 at $5 \mu \mathrm{M}$. Curcumin at $28 \mu \mathrm{M}$ and compound 3 at $9 \mu \mathrm{M}$ induced only BCL2 and BAX expression in the treated cells as referenced to the intact cells. Curcumin at $14 \mu \mathrm{M}$ did not induce any of the tested protein expressions (Fig. 1).
As HL60 is concerned, compound 3 independently on the concentration did not induce any of the tested proteins in the cells. The strong inducer of BCL-2 and much lesser extent of survivin and BAX expression was curcumin at both used concentrations (Fig. 2).

\section{DISCUSSION}

In this paper, we used polyether substituents in order to increase the water solubility of the compound. Polyether-containing compounds act primarily by complexation and transporting metal ions through the cell membrane. This may result in the induction of apoptosis, cell cycle arrest, the occurrence of oxidative stress and loss of mitochondrial potential. As demonstrated in vitro using human melanoma cells RPMI 7951 and human breast cancer cells MDA-MB-23, the best location for the phenolic group in the curcumin molecule, in the absence of a methoxy group, in the context of cytotoxic activity, was the ortho position. The meta and para positions have proved to be less active (32).

Polyether curcumin derivatives described in this paper were obtained by the method proposed by Pabon, by condensation of aldehydes substituted with a polyether chain with acetylacetone (31). This kind of derivatives has not been described in the literature so far, and therefore their biological activity has not been known. According to the literature 
data, the conversion of the hydroxyl group on the aromatic ring of curcumin into methyl ether increases the cytotoxic activity of the compound, as demonstrated in the studies with, among others, human breast cancer cells MCF-7 SKBR3, human lung cancer cells A-549, human kidney cancer cells CAKI-1 or human leukemia cells HCT-8. The compounds with the above modification showed greater stability in vitro and in vivo $(8,27)$. For these reasons, attempts have been made to modify the molecule of curcumin through the introduction of polyether (i.e. 3,6-dioxaheptoxyle) substituents to the aromatic ring in place of the hydroxyl or methoxy groups. The introduction of polyether as a substituent or substituents that contain oxygen atoms in their structure, which may form hydrogen bonding with water particles, could increase the water solubility of the obtained compounds, and thus improve the pharmacokinetic parameters of the possible medicinal products containing these compounds. The replacement of the oxygen atom in the aromatic ring by other atom results in a loss of the anticancer activity of the compound (28). Thus, the modifications described in this paper included the introduction of substituents linked to the aromatic ring through oxygen atoms in the molecule.

All derivatives obtained in this study can be solved in water. These compounds acquire a better water solubility as a result of the introduction of a polyether substituent, which has been confirmed by the literature reports (33-35).

The importance of the presence of the methoxy substituents for the cytotoxic activity of the compounds has been extensively described in the literature $(10,26,27)$. For confirmation, compound $\mathbf{3}$ obtained in this study, in which the methoxy group in the meta position (like in curcumin) was maintained, and the polyether substituent was attached to a hydroxyl group in the para position, exhibited the highest biological activity among the newly synthesized compounds. Compound $\mathbf{3}$ was modified by substitution of two hydroxyl groups with polyether substituents, i.e. 3,6-dioxaheptoxyl moieties. Most of the remaining compounds (compounds $\mathbf{1 , 2 , 4 , 5}$, 7), which were modified by introducing one, two or three polyether substituents into each aromatic ring of curcumin in place of a hydroxy or methoxy group, showed cytotoxic activity that was comparable or even lower as compared to curcumin. These observations may indicate the important role of the methoxy substituent in the meta position for the cytotoxic activity of the tested compounds.

However, a satisfactory activity of compound $\mathbf{3}$ was unfortunately non-selective. Selectivity towards cancer cells is a property that is desired for a potential therapeutic application of the tested anticancer therapeutics. In this study, cell-specificity was seen only for compound $\mathbf{6}$ which had no methoxy or hydroxyl substituents. Instead of this, three 3,6-dioxaheptyle substituents were added to each of the aromatic rings. Unfortunately, the activity of this compound against the tested cancer cells was comparable to the native molecule, i.e. curcumin. Taking into account the effects obtained for compound $\mathbf{3}$ and 6, it appears that increasing number of polyether substituents while removing methoxy groups does not increase the cytotoxicity of the compound despite the structural modifications which should improve water solubility $(12,28,36)$.

When comparing the cytotoxic activity of compounds 1, 2, 5 and $\mathbf{6}$ it can be seen that extension of the polyether chain implies the biological activity against the normal cells tested, while the number of polyether chains in the molecule does not affect cytotoxicity.

It is worth to note that ring polyether present in the molecule (compound 7) affected the lower cytotoxicity against the normal cells as compared to the polyether chains not connected in a ring (compound 2).

Compound 4 has substituents identical to compound $\mathbf{3}$ in its structure but in an inverted position a methoxy group in the para position, and a 3,6-dioxaheptyl substituent in the meta position. As was shown in this study, such modification of the curcumin molecule did not affect cytotoxic activity towards both cell lines.

In light of the results of this study, it can be concluded that the mutual positions of the methoxy and polyether (3,6-dioxaheptyl) substituents may have an effect on the cytotoxic activity of a compound. The compounds in which the methoxy group is in the same position as in the unmodified curcumin, i.e. in the meta position, show stronger cytotoxic activity. Unfortunately, such increased activity is not accompanied by selectivity of this effect for cancer cells, which is unfavorable from the therapeutic point of view.

The effect of the degree of hydrophilicity of curcumin derivatives on their cytotoxic activity has not been studied so far $(10,37,38)$. The more interesting are the results obtained in this study, in which the derivatives lacking the methoxy group (compounds $1,2,5,6,7$ ), replaced by a polyether substituent (compounds $\mathbf{1}, \mathbf{2}, \mathbf{6}, \mathbf{7}$ ) or a hydrogen atom (compound 5), despite a better solubility in water, showed similar or lower activity against the cancer cells as compared to curcumin. At the same time, these derivatives were not more cytotoxic against 
the normal cells than curcumin. As was shown in the studies with compound 2 , lack of the anticancer activity could be the result of the lack of a methoxy group, and at the same time, it may confirm its importance for the anticancer activity and/or difficult penetration of hydrophilic compounds through the cell membrane, which is not the case of the molecules that have polyether substituents in their structure.

Based on these experiments, the directions for further works could be indicated with respect to the modifications of the curcumin molecule to obtain a compound that would be more cytotoxic and selective to cancer cells. It seems that the optimal solution would be to combine the properties of compounds $\mathbf{3}$ as most cytotoxic and 6 as most selective towards HL60 cells in a single structure. Based on this study it can be suggested which modifications should be collectively taken into account in the further plans for the exploration of efficient and selective analogs of curcumin, i.e. the introduction of the ring form of polyether substituents, and leaving a methoxy group in the meta position, with simultaneous introduction of a polyether substituent in the para positions.

Given the importance of the position of each substituent in the molecule of the synthesized and tested derivatives for their cytotoxic activity, it could be useful to synthesize and evaluate also compounds with substituents in the ortho position of the aromatic ring.

Apoptotic activity of the obtained derivatives in human normal B-cells and leukemic cells was evaluated as referenced to the unmodified curcumin molecule.

BCL-2 is a membrane protein anchored in the membrane by its C-terminal transmembrane domain. This protein forms a dimer with the proapoptotic BAX protein, which prevents its participation in the apoptotic processes (39-41). In turn, $\mathrm{BAX}$, in its pro-apoptotic function, causes mitochondrial membrane depolarization, facilitating cytochrome c escape from the mitochondria, which induces the apoptotic protein cascade (40, 42). Curcumin has the ability to activate BAX (14). Another important protein that regulates apoptosis is survivin, an anti-apoptotic protein. It is capable of blocking caspase- -3 and -7 activation by binding to their active forms and inhibiting pro-caspase activation (42-45). Elevated survivin expression is observed in cancer cells (42).

According to literature reports, curcumin has the ability to selectively induce apoptosis in cancer cells, without such effect on the normal cells (20, 46). In this study, the desired selectivity in apopto- sis induction has not been confirmed for any newly synthesized derivatives. Compound $\mathbf{3}$ induced apoptosis only in the normal cells.

The lack of curcumin effect on survivin expression, observed in GM 14667cells is consistent with the results of Zhu et al. (47) obtained in normal human bronchial epithelial cells BEAS-2B. The cells were exposed for $24 \mathrm{~h}$ to curcumin at a concentration of $50 \mu \mathrm{M}$, and the culture conditions and time of exposure were the same as in our study. For lower concentrations of curcumin $(5 \mu \mathrm{M})$, there was also no increase in survivin expression $(32,47)$. As regards the cancer cells, Bush et al. (44), studying human melanoma cell lines: MMANA, MMRU, RPEP, PMWK, Sk-mel-2, Sk-mel-5, Sk-mel-28, and MEWO reported the lack of effect of curcumin also on the BCL-2 protein. In our study, there was a slight increase in BCL-2 protein expression in HL60 cells exposed to curcumin $28 \mu \mathrm{M}$, which could indicate cell-specificity of the phenomenon. Kuo et al. (21) showed that HL60 cells exposed to curcumin at a lower as compared to our studies concentration, i.e. $19 \mu \mathrm{M}$ for one to $12 \mathrm{~h}$ caused a decrease in BCL-2 expression. Similar results were obtained for human prostate cancer cells DU145 and $\operatorname{LNCaP}(21,48)$. In our at both studied concentrations of curcumin only increase in BCL-2 expression was noted.

There are no reports in the literature on the metabolic products of polyether derivatives of curcumin. It can be expected that the typical curcumin metabolic transformation involving the conjugation of curcumin with the rest of sulfuric acid or glucose by a phenol group on the aromatic ring does not occur or is difficult. This is related to the blocking of the hydroxyl groups on the aromatic ring with the polyether substituent. In this regard, it can be expected that the metabolic rate for the resulting curcumin derivatives will be reduced. One possible metabolic pathway, which the polyether curcumin derivatives may potentially undergo, is the conversion to polyether derivatives of ferulic acid. However, so far nothing is known about the biological properties of such modified molecule of this acid. It is known that ferulic acid itself is practically biologically inactive (1). An alternative metabolic pathway of the compounds may involve hydrolysis of the polyether bond to free curcumin.

\section{CONCLUSIONS}

On the basis of the results obtained in this study, it can be said that the solubility of curcumin derivatives does not directly correlate with its cytotoxicity. Maintenance of a methoxy group in the 
meta position and introduction of polyether substituents in the para positions but not the number of polyether substituents in curcumin molecule may affect the cytotoxic activity of such derivative against cancer cells. Cell specificity is probably determined by chain/ring form of the polyether substituent and its chain length.

However, on the basis of the obtained results, it can be said that a change in the molecular structure of curcumin may determine its effect on the profile of apoptotic proteins and cell-specificity in apoptosis induction.

\section{Funding}

This work was in part supported by the EU through the European Social Fund, contract number UDA-POKL.04.01.01-00-072/09-00 and in the biological part of experiments by the research fund from Polish Minsistry of Science and Higher Education.

\section{Conflict of interests}

The authors declare no conflict of interest.

\section{REFERENCES}

1. Deters M., Knochenwefel H., Lindhorst D., Koal T., Meyer H.H., et al.: Pharm. Res. 25, 1822 (2008).

2. Priyadarsini K.J.: Molecules 19, 20091 (2014).

3. Aggarwal B.B., Sung B.: Trends Pharmacol. Sci 30, 85 (2009).

4. Lampe V., Miłobędzka J.: Chem. Ber. 46, 2235 (1913).

5. Bengmark S., Mesa M.D., Gil A.: Nutr. Hosp. 24, 273 (2009).

6. Caruso F., Pettinari C., Marchetti F., Rossi M., Opazo C., et al.: Bioorg. Med. Chem. 17, 6166 (2009).

7. Sarkar F.H., Li Y.W., Wang Z.W., Kong D.J.: Cell Signal 21, 1541 (2009).

8. Hatcher H., Planalp R., Cho J., Tortia F.M., Torti S.V.: Cell Mol. Life Sci. 65, 1631 (2008).

9. Lev-Ari S., Vexler A., Starr A., AshkenazyVoghera M., Greif J., et al.: Cancer Invest. 25, 411 (2007).

10. Deptuła T., Gruber B., Krówczyński A.: Post. Fitoter. 3, 155 (2014), (in Polish).

11. Jagetia G.C., Aggarwal B.B.: J. Clin. Immunol. 27, 19 (2007).

12. Ferrari E., Arezzini B., Ferrali M., Lazzari S., Pignedoli F., et al.: Biometals 22, 701 (2009).
13. Changtam C., de Koning H.P., Ibrahim H., Sajid M.S., Gould M.K., et al.: Eur. J. Med. Chem. 45, 941 (2010).

14. Shehzad A., Wahid F., Lee Y.S.: Arch. Pharm. 343, 489 (2010).

15. Anand P., Sundaram C., Jhurani S., Kunnumakkara A.B., Aggarwal B.B.: Cancer Lett. 267, 133 (2008).

16. Ravindran J., Subbaraju G.V., Ramani M.V., Sung B.Y., Aggarwal B.B.: Biochem. Pharmacol. 79, 1658 (2010).

17. Tamvakopoulos C., Dimas K., Sofianos Z.D., Hatziantoniou S., Han Z.Y., et al.: Clin. Cancer Res. 13, 1269 (2007).

18. Das K.C., Das C.K.: Biochem. Biophys. Res. Commun. 295, 62 (2002).

19. Atsumi T., Tonosaki K., Fujisawa S.: Arch. Oral Biol. 51, 913 (2006).

20. Piwocka K., Zablocki K., Wieckowski M.R., Skierski J., Feiga I., et al.: Exp. Cell. Res. 249, 299 (1999).

21. Kuo M.L., Huang T.S., Lin J.K.: Biochim. Biophys. Acta-Mol. Basis Dis. 1317, 95 (1996).

22. Chandru H., Sharada A.C., Bettadaiah B.K., Kumar C.S.A., Rangappa K.S., et al.: Bioorg. Med. Chem. 15, 7696 (2007).

23. Anand P., Thomas S.G., Kunnumakkara A.B., Sundaram C., Harikumar K.B., et al.: Biochem. Pharmacol. 76, 1590 (2008).

24. Tomren M.A., Masson M., Loftsson T., Tonnesen H.H.: Int. J. Pharm. 338, 27 (2007).

25. Kunwar A., Barik A., Pandey R., Priyadarsini K.I.: Biochim. Biophys. Acta-Gen. Subj. 1760, 1513 (2006).

26. Amolins M.W., Peterson L.B., Blagg B.S.J.: Bioorg. Med. Chem.17, 360 (2009).

27. Gallardo H., Conte G., Tuzimoto P.A., Behramand B., Molin F., et al.: Liq. Cryst. 39, 1099 (2012).

28. Ishida J., Ohtsu H., Tachibana Y., Nakanishi Y., Bastow K.F., et al.: Bioorg. Med. Chem. 10, 3481 (2002).

29. Feng J.Y., Liu Z.Q.: J. Agric. Food Chem. 57, 11041 (2009).

30. Kryatova O.P., Kolchinski A.G, RybakAkirnova E.V.: Tetrahedron 59, 231 (2003).

31. Pabon H. J.J.: Recl. Trav. Chim. Pays-Bas-J. Roy Neth. Chem. Soc. 83, 379 (1964).

32. Simon A., Allais D.P., Duroux J.L., Basly J.P., Durand-Fontanier S., et al.: Cancer Lett. 129, 111 (1998).

33. Majithiya J.B., Balaraman R., Giridhar R., Yadav M.R.: J. Trace Elem. Med. Biol. 18, 211 (2005). 
34. Sui Z., Salto R., Li I., Craik C., Ortiz de Montellano P.R.: Bioorg. Med. Chem. 1, 415 (1993).

35. Linsley P.S., Bradshaw J., Greene J., Peach R., Bennett K.L., et al.: Immunity 4, 535 (1996).

36. Benassi R., Ferrari E., Grandi R., Lazzari S., Saladini M.: J. Inorg. Biochem. 101, 203 (2007).

37. Aziz M.T.A., El Asmer M.F., Rezq A., Kumosani T.A., Mostafa S., et al.: J. Sex Med. 7, 2714 (2010).

38. Aziz M.T.A., El Asmer M.F., Kumar S., Narain U., Tripathi S., Misra K.: Bioconjugate Chem. 12, 464 (2001).

39. Haldar S., Basu A., Croce C.M.: Cancer Res. 57, 229 (1997).

40. Aggarwal B.B., Ichikawa H.: Cell Cycle 4, 1201 (2005).
41. Basu A., Haldar S.: Mol. Hum. Reprod. 4, 1099 (1998).

42. Tamm I., Wang Y., Sausville E., Scudiero D.A., Vigna N., et al.: Cancer Res. 58, 5315 (1998).

43. McCabe M.L., Dlamini Z.: Int. Immunopharmacol. 5, 1113 (2005).

44. Bush J.A., Cheung K.J.J., Li G.: Exp. Cell Res. 271, 305 (2001).

45. Li F.Z., Ambrosini G., Chu E.Y., Plescia J., Tognin S., et al.: Nature 396, 580 (1998).

46. Han S.S., Chung S.T., Robertson D.A., Ranjan D., Bondada S.: Clin. Immunol. 93, 152 (1999).

47. Zhu W.B., Cromie M.M., Cai Q.S., Lv T.F., Singh K., et al.: PLoS One 9, e92992 (2014).

48. John V.D., Krishnankutty K.: Appl. Organomet. Chem. 20, 477 (2006).

(C) 2020 by Polish Pharmaceutical Society. This is an open access article under the CC BY NC license (c) (1) (8) (http://creativecommons.org/licenses/BY/4.0/). 